visits, and might perhaps even abolish some of the restrictions to normal trade relations which at present prevent the import of badly needed British scientific research equipment into Hungary. A conversation with Academician Bognár, general secretary to the Hungarian Acadomy of Sciences, gave grounds for hope that the Academy might actively support projects for a more liberal exchange of visits of individual scientists between Britain and Hungary in the near future.

Meanwhile, it is encouraging to learn that a party of Hungarian scientists has recently visited Britain, under the auspices of the World Federation of Scientific Workers and the British Association of Scientific Workers; and that METESZ is to repeat its group invitations (begun in 1954) to British and French scientists next year. METESZ and its hardworking and imaginative secretary (Dr. E. Valko) and assistant secretary (Mrs. Barbara Striker) are indeed to be congratulated on having taken one of the first steps to break the ice. M. R. PoLLOCK

\section{DEVELOPMENT AND WELFARE IN THE BRITISH COLONIES}

$\mathrm{T}$ HE schemes made under the Colonial Development and Welfare Acts, covering the period April 1, 1954-March 31, 1955, which are detailed in the latest return*, bring the total commitments for development and welfare schemes under the Acts to $£ 123,402,27 \mathrm{I}$, and for research schemes to $£ 12,908,139$, of which $£ 14,757,289$ and $£ 533,548$, respectively, are

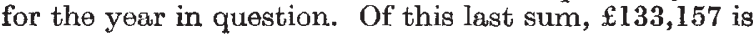
for agriculture, $£ 83,767$ for medicine, $£ 54,413$ for locust control, $£ 47,589$ for insecticides, $£ 25,553$ for social science, $£ 9,042$ for economic research, $£ 6,795$ for products research, $£ 6,200$ for fisheries and $£ 2,250$ for tsetse and trypanosomiasis.

Of the actual research schemes, $£ 104,024$ was for the establishment and maintenance for two years of the East African Scientific and Industrial Research Organization, a further $£ 42,500$ for the East African Medical Survey, $£ 50,000$ for the establishment and maintenance of the Colonial Road Research Section at the Road Research Laboratory, Harmondsworth, a further $£ 37,750$ for the maintenance of the AntiLocust Research Centre and extra-mural activities, $£ 31,483$ for the purchase of buildings at Kavete for the East African Veterinary Research Organization, $\mathfrak{1 2 2 , 3 2 9}$ to establish an Agricultural Research Station at Aden, $£ 17,780$ for sylvicultural research in Nyasaland, a further $£ 16,365$ to maintain the Ebini Livestock Experimental Station in British Guiana, a further $£ 16,663$ for the Desert Locust Survey and $£ 14,390$ for the maintenance of the Colonial Insecticides Research Unit at Porton.

In West Africa, $£ 10,955$ was provided for the establishment of a Standing Advisory Committee for Agricultural Research and a further $£ 5,306$ for the establishment of the West African Building Research Organization, as well as $£ 4,500$ for a social and anthropological investigation of the State of Gonja, Gold Coast. In East Africa, a further $£ 8,100$ was provided for control of coconut palm pests in

* Colonial Development and Welfare Acts : Return of Schemes made under the Colonial Development and Welfare Acts by the Secretary of State for the Colonies, with the Concurrence of the Pp. 32. (London: H.M.S.O., 1955.) 1s. 3d. net.
Zanzibar ; in the Western Pacific, a further $£ 6,332$ for investigation of means of controlling Amblypelta cocophaga and other coconut pests in the British Solomon Islands ; in Sarawak, $£ 4,300$ for an investigation into the control of pepper disease ; and in the West Indies, a further $£ 4,230$ for cytogenetical research on sugar cane and $£ 6,780$ for a pilot scheme for establishment of a Nutritional Research Unit in Jamaica.

Among the major development and welfare schemes of particular scientific interest are the following : in East Africa, a further $£ 700,000$ for the desert locust control campaign and $\mathbf{£ 7 8 5 , 4 3 8}$ to intensify African agricultural development in Kenya during 1954-55; in Malaya, $£ 408,250$ for the construction of a road between Temerloh and Maran, linking the west and east coasts, $£ 204,000$ for the establishment of rural health centres, and $£ 410,000$ for the construction of a teachers' training college at Penang in British Guiana, and a further $£ 72,750$ for geological survey, as well as $£ 35,000$ for aerial survey and $£ 20,833$ for hydrographic and hydrological surveys. In British Honduras, a further $£ 38,075$ was provided for the artificial regeneration of pine, $£ 29,555$ for rice investigation and $£ 45,200$ for afforestation of pine savannah. Among a series of grants to the University College of the West Indies are $£ 10,000$ for the establishment of a Department of Chemical Technology and a further $£ 10,000$ for scientific equipment. $£ 11,450$ was provided for rice research in the British Solomon Islands Protectorate, and $£ 33,500$ for an aerial survey of Fiji. In West Africa, besides $£ 99,314$ for senior staff housing for the Nigerian College of Arts, Science and Technology, a further $£ 150,000$ for road development in the Cameroons and various contributions to Fourah Bay College (including $£ 27,000$ for additional laboratory and library accommodation), a supplementary contribution of $£ 3,763,351$ to the Development Plan for Nigeria includes substantial grants, distributed over all the regions, for agriculture (totalling $£ 615,113$ ), general

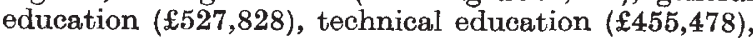
forestry ( $£ 83,315)$, leprosy control ( $£ 217,793)$, medical

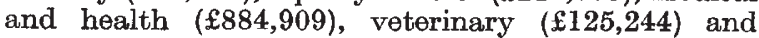
fisheries $(£ 38,437)$.

\section{ECONOMIC DEVELOPMENT OF BASUTOLAND, BECHUANALAND AND SWAZILAND}

A

WHITE Paper on the High Commission Territories of Basutoland, Bechuanaland and Swaziland* gives a concise picture of the economic development and social services in these three territories, to which since 1945 nearly $£ 14,144,000$ has been granted or earmarked. Of this, nearly $£ 3 \frac{3}{4}$ million was from Colonial Development and Welfare Funds available for 1945-56, and a further £3 million has been allocated under the 1955 Act for the period to 1960. The Colonial Development Corporation has embarked on projects in the Bechuanaland Protectorate and in Swaziland, for which capital sanction of $£ 7,299,000$ has been given; of this amount, $£ 4,424,000$ had been spent by the end of 1954, and, according to present plans, full development of these projects may involve expendi-

* High Commission Territories : Economic Development and Social 